\title{
Race, consanguinity and social features in Birmingham babies: a basis for prospective study
}

\author{
Sarah Bundey, Hasina Alam, Amritpal Kaur, Samina Mir, R J Lancashire
}

\begin{abstract}
Study objective-The aim of the study was to investigate the influence of consanguinity on children's health.

Design-The study is a prospective survey from birth to five years of a cohort of babies born in a multiracial community. This report details the initial findings on consanguinity.
\end{abstract}

Setting-Participating families live predominantly in three health districts of Birmingham, and were recruited in three local maternity hospitals.

Participants-Babies of 2432 European mothers, 509 Afro-Caribbean mothers, 625 Indian mothers, 956 Pakistani mothers, and 216 Bangladeshi mothers have been enrolled in the study. Eighty mothers refused to participate.

Measurements and results-Sociodemographic information was obtained using a structured questionnaire administered at interview. Interview data were supplemented with obstetric information from the medical records. The highest prevalence of parental consanguinity was in Pakistani Muslims (69\%), whereas in Muslims from other countries it was $23 \%$, and it was less than $1 \%$ in non-Muslims. In the majority of consanguineous Muslim pedigrees the degree of inbreeding was greater than that for first cousin parents.

Conclusions-This prospective study will allow an assessment to be made about any ill health in childhood arising from parental consanguinity, about whether screening programmes are indicated for particular autosomal recessive diseases, and about whether premarital health education might be beneficial. The study has also documented parental ages in different races and this, together with the levels of parental consanguinity in all races, will be useful in genetic methods for assessing the frequency of recessive genes, the possibility of genetic heterogeneity, and whether or not parental age effect exists for new mutations of specific genetic disorders.

There is evidence that Pakistanis in the United Kingdom have a higher perinatal mortality rate and a higher incidence of handicapping childhood disorders than do the other races. ${ }^{1-7}$ Some of these problems may be related to the lower socioeconomic status of the Pakistanis, to the older ages of their mothers, or to non-immunity to rubella and other viruses, as well as to other factors. ${ }^{8}$ One additional feature of Pakistanis which may be relevant to the development of diseases of infancy and childhood is their tendency to marry relations ${ }^{149}$, so that autosomal recessive diseases appear in their offspring. In order to investigate this further we planned a prospective study in which details of parental consanguinity could be documented along with other sociodemographic features which might influence childrens' health. As Birmingham is a multiracial city, there was the opportunity to study these features not just in Pakistanis, but in other races as well, which would enable an extra aim of the study to be fulfilled, namely the collection of modern figures on levels of parental consanguinity and parental ages, which would be useful for genetic methods of estimating disease frequency, ${ }^{10}$ for demonstrating heterogeneity at different loci, ${ }^{11}$ or for assessing whether older parental ages are significant in the aetiology of chromosomal and single gene mutations. ${ }^{12}$

\section{Methods}

We chose to study residents from the City of Birmingham where the ethnic minority groups live mainly in Central, West and East Health Districts. We chose for the study three maternity hospitals that serve these districts: Birmingham Maternity Hospital, Dudley Road Hospital and Marston Green Hospital. Permission for the study was obtained from the obstetricians, neonatal paediatricians and nursing staff of these three maternity hospitals, from the ethical committees of the five Birmingham health districts, and from their District Medical Officers. The study started on January 1st, 1986, and the documentation of newborn babies continued for 16,14 and 12 months respectively at the three hospitals. The babies will be followed up until they enter school at the age of five years.

Posters and information leaflets written in four languages (English, Punjabi, Urdu and Bangladeshi) were displayed in the antenatal clinics. Mothers were interviewed in the postnatal wards where possible, or were seen at home if an early discharge had prevented an interview in hospital. Mothers of both liveborn and stillborn children were approached. They were told about the prospective study, given another information leaflet, and then asked for permission for their baby (or babies) to be included. If they agreed, a twelve page questionnaire was used to obtain information concerning their health, diet, language, exposure to drugs, alcohol or tobacco, length of antenatal care, job, age, family history, place of birth and race. There were six categories 
for race: European included those who originated in Britain, Ireland or continental Europe; AfroCaribbean included blacks of African or West Indian origin; Indian included both those from India and those who had emigrated from India to East Africa; Pakistani and Bangladeshi individuals originated in those two countries, and "other" included those not falling into the above categories, including those of mixed race. At the interview, information was also requested about the age and job of the father of the baby, and whether the mother was related to him. The family history consisted of taking a pedigree which extended to the baby's grandparents if there was no consanguinity, but which included at least great grandparents if consanguinity was present. If there was more than one consanguineous marriage among the baby's ancestors an attempt was made to note them all, for the parental and three preceeding generations. The interview information was supplemented from the medical records to provide data on the number of antenatal visits, weight gained during pregnancy, type of labour and delivery, and measurements of the baby.

Not all the mothers giving birth in the period study could be included, owing to difficulties in covering for weekends, other holidays, or periods of sickness. At Dudley Road and Marston Green hospitals, births occurring on five or six days each week were usually included, but fewer mothers were seen at Birmingham Maternity Hospital where staff worked part time. A decision was made about whether or not a particular day should be included before looking at the labour ward books, and once a day had been chosen, it was completed even if home visits were required in order to see mothers who had been discharged early.

The degree of inbreeding of babies with parental consanguinity was quantified by the inbreeding coefficient $(F)$. This is a measure of the probability that an individual will have

Four commonly encountered pedigrees, where $F=$ inbreeding coefficient.
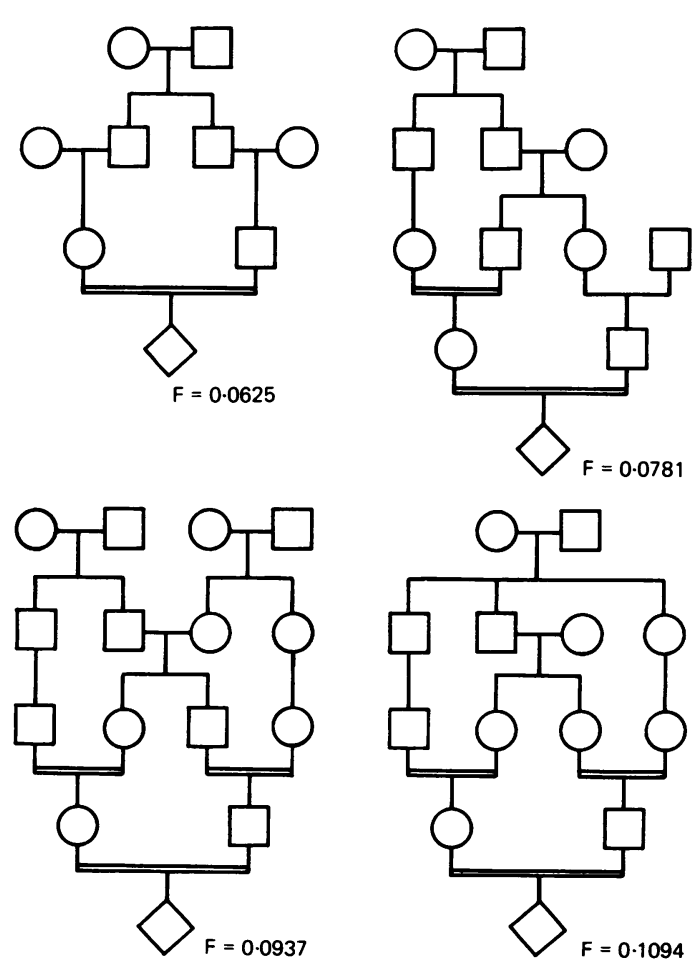

inherited the same gene, through both parents, from each and every common ancestor. ${ }^{13}$ Some examples of pedigrees with their inbreeding coefficients encountered in this study are presented in the figure. For comparison, the inbreeding coefficient for the offspring of uncleniece unions is 0.125 and for the offspring of father-daughter unions is $\mathbf{0 . 2 5}$.

\section{Results}

The annual birth rate for babies with addresses in the City of Birmingham is about 16000 . During the period of the study, 9878 mothers from the City of Birmingham had babies at Dudley Road Hospital, Marston Green Hospital and Birmingham Maternity Hospital. However, only 4966 of these delivered on study days, the remainder having babies during weekends, annual holidays or periods of sick leave. Of these 4966 mothers, 4886 agreed to participate. This number comprised 2417 mothers from Dudley Road Hospital ( $75 \%$ of its total deliveries of City babies), 969 mothers from Marston Green Hospital ( $60 \%$ of its deliveries) and 1561 mothers from Birmingham Maternity Hospital (31\% of its deliveries of City babies). Eighty mothers refused to participate.

The $\mathbf{4 8 8 6}$ mothers who agreed to participate had 4934 babies. Ninety six babies (48 pairs) were twins. There were also five babies who had been twins but whose cotwins had died in utero before 24 weeks gestation. The rate of twinning was $1.2 \%$ for English babies, $0.8 \%$ for Indian and Pakistani babies and $2.0 \%$ for Afro-Caribbean babies.

The 4934 babies consisted of 2526 males and 2408 females. Four thousand nine hundred babies were liveborn (including 25 between 24 and 28 weeks gestation) and 33 were stillborn (six between 24 and 28 weeks gestation). No information was obtained about abortions occurring at 23 weeks or earlier.

Of the mothers, 2432 were European, 509 were Afro-Caribbean, 625 were Indian, 956 were Pakistani, 216 were Bangladeshi, and 196 belonged to other races (Arabs, Chinese, Vietnamese, and mixed Afro-Caribbean/English or Asian/English origin). Among the babies in the study, $190(3.8 \%)$ were the offspring of mixed marriages; this figure can be compared to $1.4 \%$ of parents (88 mothers and 58 fathers) who were themselves the offspring of mixed marriages.

Regarding religion, $89 \%$ of the Europeans and $74 \%$ of the Afro-Caribbeans were Christians; the Indians consisted of $54 \%$ Sikhs, $33 \%$ Hindus and $10 \%$ Muslims, the latter being mainly Indians from East Africa. All but nine of the Pakistani and Bangladeshi mothers were Muslims. Other religions of mothers in the study included Rastafarianism, Buddhism and Taoism. Further features of the mothers and fathers, subdivided by race, are summarised in tables I and II and illustrate the older ages of Pakistani and Bangladeshi parents, their larger families, their shorter attendances at antenatal clinics, and their lower social classes as judged by the occupations of the fathers of their babies.

Of the European mothers, $2336\left(96^{\circ}{ }_{0}\right)$ were born in the United Kingdom. In the Afro- 
Table I Some features of mothers, according to their race. Data are total numbers with percentages in brackets

Table II Some features of fathers, according to their race. Data are percentages
Table III Mothers born outside the United Kingdom. Data are percentages

\begin{tabular}{|c|c|c|c|c|c|c|}
\hline \multirow[b]{2}{*}{ Feature of mother } & \multicolumn{6}{|l|}{ Race of mother } \\
\hline & $\begin{array}{l}\text { European } \\
(\mathrm{n}=2432)\end{array}$ & $\begin{array}{l}\text { Afro-Caribbean } \\
(n=509)\end{array}$ & $\begin{array}{l}\text { Indian } \\
(n=625)\end{array}$ & $\begin{array}{l}\text { Pakistani } \\
(\mathrm{n}=956)\end{array}$ & $\begin{array}{l}\text { Bangladeshi } \\
(\mathrm{n}=216)\end{array}$ & $\begin{array}{l}\text { Other } \\
(n=196)\end{array}$ \\
\hline Aged under 20 & $310(13)$ & $83(16)$ & $35(6)$ & $118(12)$ & $28(13)$ & $29(15)$ \\
\hline Aged 40 or over & $37(1 \cdot 5)$ & $4(0 \cdot 8)$ & $8(1 \cdot 2)$ & $47(4 \cdot 9)$ & $12(5 \cdot 5)$ & $4(2 \cdot 0)$ \\
\hline No previous children & $763(31)$ & $159(31)$ & $188(30)$ & $213(22)$ & $27(12)$ & $43(22)$ \\
\hline 1,2 , or 3 previous children & $1421(58)$ & $279(55)$ & $374(60)$ & $430(45)$ & $87(40)$ & $121(62)$ \\
\hline 4 or more previous children & $248(10)$ & $71(14)$ & $63(12)$ & $313(33)$ & $102(47)$ & $32(16)$ \\
\hline Married to father of baby & $1547(64)$ & $127(25)$ & $611(98)$ & $946(99)$ & $216(100)$ & $106(54)$ \\
\hline $\begin{array}{l}\text { If unmarried, number in stable } \\
\text { relationship with father }\end{array}$ & $623 / 885(71)$ & $283 / 382(74)$ & $9 / 14(64)$ & $5 / 10(50)$ & - & $50 / 90(55)$ \\
\hline Booked before 10 weeks & $460 / 2400(19)$ & $50 / 502(10)$ & $72 / 618(12)$ & $56 / 945(6)$ & $21 / 214(10)$ & $16 / 178(9)$ \\
\hline Booked after 16 weeks & $604 / 2400(25)$ & $211 / 502(42)$ & $212 / 618(34)$ & $536 / 945(57)$ & $114 / 214(53)$ & $82 / 178(46)$ \\
\hline Fewer than 10 antenatal visits & $730 / 2240(33)$ & $211 / 478(44)$ & $181 / 588(31)$ & $507 / 882(57)$ & $105 / 205(51)$ & $94 / 188(50)$ \\
\hline Worked in pregnancy & $917(38)$ & 191 (37) & $231(37)$ & $23(2)$ & $6(3)$ & $33(17)$ \\
\hline Smoked in pregnancy & $963(39)$ & $152(30)$ & $5(1)$ & $13(1)$ & $20(9)$ & $54(27)$ \\
\hline Drank alcohol in pregnancy & $252(10)$ & $32(6)$ & 2 & $\mathbf{0}$ & 0 & $12(6)$ \\
\hline
\end{tabular}

*More than two glasses per week

\begin{tabular}{|c|c|c|c|c|c|c|}
\hline \multirow[b]{2}{*}{ Feature of father ${ }^{\star}$} & \multicolumn{6}{|c|}{ Race of father } \\
\hline & $\begin{array}{l}\text { European } \\
(n=2213)\end{array}$ & $\begin{array}{l}\text { Afro-Caribbean } \\
(n=546)\end{array}$ & $\begin{array}{l}\text { Indian } \\
(n=630)\end{array}$ & $\begin{array}{l}\text { Pakistani } \\
(\mathbf{n}=971)\end{array}$ & $\begin{array}{l}\text { Bangladeshi } \\
(\mathbf{n}=230)\end{array}$ & $\begin{array}{l}\text { Other } \\
(n=182)\end{array}$ \\
\hline Born in UK & $93 \cdot 2$ & $50 \cdot 7$ & $15 \cdot 1$ & $5 \cdot 2$ & $2 \cdot 9$ & $37 \cdot 8$ \\
\hline Aged under 20 & $4 \cdot 6$ & $5 \cdot 4$ & $1 \cdot 2$ & $4 \cdot 3$ & $1 \cdot 0$ & $4 \cdot 8$ \\
\hline Aged over 40 & $7 \cdot 0$ & $9 \cdot 1$ & $4 \cdot 3$ & $15 \cdot 5$ & $43 \cdot 2$ & $12 \cdot 4$ \\
\hline \multicolumn{7}{|c|}{ Social class by last job } \\
\hline I & $5 \cdot 7$ & 1.0 & 3.5 & 1.0 & 1.4 & 5.5 \\
\hline II & $10 \cdot 8$ & $4 \cdot 1$ & 6.0 & $2 \cdot 0$ & 0.5 & $12 \cdot 3$ \\
\hline III non-manual & 13.6 & $8 \cdot 1$ & $20 \cdot 8$ & $9 \cdot 1$ & 5.5 & $12 \cdot 3$ \\
\hline III manual & 29.9 & 36.0 & $17 \cdot 0$ & $8 \cdot 6$ & $22 \cdot 0$ & $21 \cdot 0$ \\
\hline IV \& Vt & 31.9 & $31 \cdot 3$ & $45 \cdot 1$ & 61.6 & $67 \cdot 0$ & $34 \cdot 6$ \\
\hline Unemployed now & 31.7 & $49 \cdot 0$ & $29 \cdot 0$ & $49 \cdot 0$ & $58 \cdot 2$ & $53 \cdot 1$ \\
\hline Never worked & $2 \cdot 8$ & $7 \cdot 7$ & $4 \cdot 1$ & $11 \cdot 2$ & $3 \cdot 7$ & $14 \cdot 2$ \\
\hline
\end{tabular}

No information was available for 162 fathers, the jobs of a further 456 fathers were not known by their partners, and the ages of a further 565 fathers were not known

tMany Asian wives were unable to describe their husband's occupation accurately enough for distinction between social classes IV and $\mathrm{V}$ to be made.

\begin{tabular}{|c|c|c|c|c|c|c|}
\hline & \multicolumn{6}{|c|}{ Race of mother ${ }^{\star}$} \\
\hline & $\begin{array}{l}\text { European } \\
(\mathbf{n}=96)\end{array}$ & $\begin{array}{l}\text { Afro-Caribbean } \\
(n=160)\end{array}$ & $\begin{array}{l}\text { Indian } \\
(n=518)\end{array}$ & $\begin{array}{l}\text { Pakistani } \\
(\mathbf{n}=889)\end{array}$ & $\begin{array}{l}\text { Bangladeshi } \\
(n=215)\end{array}$ & $\begin{array}{l}\text { Other } \\
(n=88)\end{array}$ \\
\hline In $U K=10$ years & 64 & 86 & 42 & 17 & 6 & 18 \\
\hline In UK 5-10 years & 13 & 7 & 31 & 43 & 39 & 21 \\
\hline In UK < 5 years & 23 & 7 & 26 & 39 & 55 & 61 \\
\hline English first language & 90 & 96 & 5 & 1 & 0 & 7 \\
\hline Could speak Englisht & 98 & 99 & 77 & 28 & 26 & 65 \\
\hline Met interpreter in antenatal clinic & 0 & $\mathbf{0}$ & 20 & 67 & 53 & 2 \\
\hline Neither of above & 2 & 1 & 3 & 5 & 21 & 33 \\
\hline Booked $<10$ weeks of gestation & 14 & 11 & 12 & 6 & 9 & 11 \\
\hline Booked 10-16 weeks & 57 & 52 & 54 & 37 & 37 & 43 \\
\hline Booked after 16 weeks & 28 & 37 & 34 & 57 & 54 & 46 \\
\hline \multicolumn{7}{|l|}{ Father of baby $\neq$} \\
\hline $\begin{array}{l}\text { Social class } \\
\text { I II or III non-manual }\end{array}$ & 37 & 25 & 31 & 13 & 7 & 36 \\
\hline $\begin{array}{l}\text { Social class } \\
\text { III manual, IV, } \mathrm{V}\end{array}$ & 60 & 70 & 64 & 77 & 90 & 43 \\
\hline Never worked & 3 & 5 & 4 & 11 & 3 & 21 \\
\hline Could speak Englisht & 100 & 100 & 95 & 91 & 91 & 85 \\
\hline
\end{tabular}

*The length of stay in the United Kingdom, and/or the date of 1st booking were not known for 26 mothers tCould speak and understand English well enough to communicate with staff in antenatal clinic †The jobs of 113 fathers were not known. 
Caribbean group, $349(69 \%)$ mothers were born in the United Kingdom, $28(5 \%)$ were born in Africa and $132(26 \%)$ were born in the West Indies. Of the Indian mothers, $107(17 \%)$ were born in the United Kingdom, $71(11 \%)$ were born in East Africa and $447(72 \%)$ were born in India. Only $67(7 \%)$ Pakistani mothers and one Bangladeshi mother were born in the United Kingdom. Various features relating to those mothers not born in the United Kingdom, such as the extent of their antenatal care, are listed in table III. It is noteworthy that only a few mothers were unable to meet an interpreter in the antenatal clinic; these were mainly mothers who spoke only Bengali, Arabic, Vietnamese, Chinese or Pashto.

The mean parental ages and the occurrence of consanguinity in the different races are presented in Table IV. The 10 instances of parental and consanguinity
Table IV Parental ages

\begin{tabular}{lllll}
\hline & & & \multicolumn{2}{c}{$\begin{array}{l}\text { Related to father } \\
\text { of baby }\end{array}$} \\
\cline { 5 - 6 } $\begin{array}{l}\text { Race of } \\
\text { mother }\end{array}$ & $\begin{array}{l}\text { Mean } \\
\text { maternal } \\
\text { age (years) }\end{array}$ & $\begin{array}{l}\text { Mean } \\
\text { paternal } \\
\text { age (years) }\end{array}$ & Number & o \\
\hline European & 26.0 & 29.2 & $10 / 2432$ & 0.4 \\
Afro-Caribbean & 24.5 & 28.3 & $3 / 509$ & 0.6 \\
Indian* & 26.2 & 28.9 & $32 / 625 \dagger$ & 5.1 \\
Pakistani & 26.7 & 31.5 & $657 / 956$ & 68.7 \\
Bangladeshi & 28.0 & 37.8 & $29 / 216$ & 13.4 \\
Other & 25.6 & 29.8 & $20 / 196$ & 10.2 \\
\hline
\end{tabular}

* Includes 71 East African Asians

t These figures could be divided further into $1 / 341\left(0.3^{\circ}\right)$ for Sikhs, $3 / 212(1.4 \%)$ for Hindus, $28 / 63(44 \cdot 4 \%$ ) for Muslims and $0 / 9$ for other religions.

Table $V$ The racial distribution of 1284 Muslim mothers, and their consanguinity

\begin{tabular}{|c|c|c|c|c|c|}
\hline \multirow{2}{*}{$\begin{array}{l}\text { Race of mother } \\
\text { Indian }\end{array}$} & \multicolumn{2}{|c|}{$\begin{array}{l}\text { Consanguineous } \\
\text { n }(\%)\end{array}$} & \multicolumn{2}{|c|}{$\begin{array}{l}\text { Non-consanguineous } \\
\text { n }(\%)\end{array}$} & \multirow{2}{*}{$\frac{\text { Total }}{63}$} \\
\hline & 28 & (44) & 35 & $(56)$ & \\
\hline Pakistani & 657 & (69) & 294 & (31) & 951 \\
\hline Bangladeshi & 29 & (14) & 183 & (86) & 212 \\
\hline Arab & 13 & (46) & 15 & (54) & 28 \\
\hline Asian/European & 6 & (40) & 9 & $(60)$ & 15 \\
\hline Others & 1 & (7) & 14 & (93) & 15 \\
\hline Totals & 734 & (57) & 550 & (43) & 1284 \\
\hline
\end{tabular}

Table VI Degrees of inbreeding in consanguineous Muslim families

\begin{tabular}{llr}
\hline Degree of consanguinity & $\begin{array}{l}\text { Range of inbreeding } \\
\text { coefficient of baby in study }\end{array}$ & Numbers \\
\hline Related but no closer than 3rd cousins & $0.0001-0.0039$ & 7 \\
Between 2nd and 3rd cousins & $0.0040-0.0155$ & 7 \\
2nd cousins & 0.0156 & 38 \\
Between 1st and 2nd cousins & $0.0157-0.0624$ & 33 \\
1st cousins & 0.0625 & 145 \\
Closer than 1st cousins & $0.0626-0.0781$ & 133 \\
Closer than 1st cousins & $0.0782-0.0937$ & 41 \\
Closer than 1st cousins & $0.0938-0 \cdot 1875$ & 51 \\
Not known precisely, but less & & 56 \\
than 1st cousins & - & 183 \\
Not known precisely, but more & & 40 \\
than 1st cousins & - & \\
Not able or willing to describe & - & \\
\hline
\end{tabular}

\footnotetext{
* See figure I for examples.
}

consanguinity among European couples consisted of one case of father/daughter incest, four pairs of first cousins, one of second cousins and four couples who were third cousins or more distantly related. Seven of the 10 couples were Roman Catholics. The three instances of consanguinity in the Afro-Caribbeans consisted of one pair of first cousins, one pair of second cousins and one couple who were distantly related. The single consanguineous Sikh couple were more distantly related than third cousins. The three consanguineous Hindu couples consisted of one pair of first cousins, one pair of first cousins once removed, and one pair of third cousins. The overall mean coefficients of inbreeding for the non-Muslim groups were 0.00022 for Europeans, 0.00016 for Afro-Caribbeans, less than 0.00001 for Sikhs and 0.00046 for Hindus. Because of the high level of consanguinity in Muslims of different races, they have been enumerated in table $V$, and subdivided by race and consanguinity. Of the total of 734 consanguineous Muslim couples, $553(75 \%$ ) were first cousins, but in $\mathbf{4 0 8}$ of these (74\%) their parents were also consanguineous, which raised the inbreeding coefficients for their children above $\mathbf{0 . 6 2 5}$. Of those $\mathbf{5 5 3}$ families where the parents of the baby were first cousins, the most common situation was that the two grandfathers were brothers. This accounted for $37 \%$ of first cousin relationships.

In 455 consanguineous pedigrees the inbreeding coefficient could be precisely measured and these are listed in table VI. The mean inbreeding coefficient for the babies of these consanguineous matings was 0.0674 ; however the true mean is likely to be higher than this, since 183 of the 279 mothers $(66 \%)$ who could not precisely describe the other consanguineous marriages in their families were married to their first cousins. If however we consider 0.0674 to be the mean inbreeding coefficient for the Muslim babies born to consanguineous parents, then the overall mean for all Muslim babies becomes 0.0384 . Altogether 471 Muslims had more than one consanguineous marriage in their pedigree.

In view of our plan to compare perinatal mortality and prevalence of childhood disability in the consanguineous and non-consanguineous groups of Muslims, of all races, we looked at other maternal and family factors in these two groups which might influence children's health, and these are summarised in table VII. The features examined were very similar in the two groups, except that the men and women who were related to their spouses were younger than those who were not. In considering this further, we observed that among Muslim women born before 1950, $48 \%$ were related to their husbands and $20 \%$ had inbreeding coefficients above 0.0625 . In contrast, among Muslim women born after $1965,67^{\circ}$ o were related to their husbands and $33 \%$ had inbreeding coefficients above $\mathbf{0 . 0 6 2 5}$. However, the differences between the two groups were not statistically significant.

The perinatal and neonatal mortality rates will be presented in a subsequent paper. In brief, there were higher perinatal and neonatal mortality rates for the Pakistanis than for other races (14.6 and 8.4 per 1000 respectively) but the differences did not reach statistical significance.

The mean birth weight and head circumference measurements when corrected for sex and gestation ${ }^{1415}$ were not different in the Muslim babies who were the offspring of consanguineous 
Table VII A comparison of Muslim mothers who were related to their husbands with those who were not

\begin{tabular}{|c|c|c|}
\hline & $\begin{array}{l}\text { Related } \\
(734)\end{array}$ & $\begin{array}{l}\text { Not Related } \\
(550)\end{array}$ \\
\hline Mean maternal age (years) & $26 \cdot 5$ & $27 \cdot 6$ \\
\hline Mean paternal age (years) & $30 \cdot 8$ & $35 \cdot 6$ \\
\hline Mothers aged under $20(\%)$ & $14 \cdot 3$ & $9 \cdot 6$ \\
\hline Mothers aged over $40(\%)$ & $5 \cdot 5$ & $4 \cdot 8$ \\
\hline Mothers born in United Kingdom $\left({ }^{\circ}{ }_{0}\right)$ & $7 \cdot 4$ & $6 \cdot 6$ \\
\hline Mothers in UK for less than 6 years $(\%)$ & 43.5 & $53 \cdot 7$ \\
\hline Mothers who could understand English $(\%)$ & $34 \cdot 0$ & $38 \cdot 6$ \\
\hline Mean length of antenatal care (weeks) & 21 & 21 \\
\hline Mothers booking after 16 weeks' gestation $(\%)$ & 55 & 53 \\
\hline \multicolumn{3}{|l|}{ Fathers' social class, by last job } \\
\hline I, II, or III non-manual $(\%)$ & 13 & 15 \\
\hline III manual IV or V $\left({ }^{\circ}\right)$ & 75 & 75 \\
\hline Never worked $(\%)$ & 12 & 10 \\
\hline \multicolumn{3}{|l|}{ Babies } \\
\hline Mean birthweight (g(SD)) & $3090(557)$ & $3162(593)$ \\
\hline Birthweight under $2500 \mathrm{~g}(\%)$ & $12 \cdot 1$ & $9 \cdot 1$ \\
\hline Gestation under 36 weeks $(\%)$ & $8 \cdot 8$ & $8 \cdot 5$ \\
\hline Mean head circumference $(\mathrm{cm})$ & $33 \cdot 7$ & 33.9 \\
\hline
\end{tabular}

marriages compared to those of nonconsanguineous marriages, nor were the distributions of these measurements different (table VII). However the birth weight distributions for all ethnic minority groups were clustered around lower mean values than the European babies. Using the centiles of Thomson et al, ${ }^{14} 5 \cdot 2 \%$ of European babies had birthweights equal to or below the 5 th centile, but the figures were $8.1 \%$ for Afro-Caribbean babies, $9.6 \%$ for Indian babies, $8.5 \%$ for the babies of consanguineous Muslims and $7.9 \%$ for the babies of non-consanguineous Muslims.

\section{Discussion}

The data were collected at the outset of a prospective study which will last for five years. They describe features of different racial and religious groups which might influence the health of babies and children. The population studied was reasonably representative of three Health Districts in Birmingham (Central, West and East), but not representative of the City of Birmingham as a whole. The proportions of ethnic groups were $49 \%$ European, $10 \%$ AfroCaribbean, $13 \%$ Indian, 19\% Pakistani, 4\% Bangladeshi and $4 \%$ other races.

The general differences in races concerning social class, degree of antenatal care, and other details which are listed in tables I and II, are not unexpected. Afro-Caribbean parents tended to be young, and Pakistani and Bangladeshi parents to be older and to have had larger numbers of previous children. Although few Afro-Caribbean parents were married, $80 \%$ of parental couples were in stable relationships, which is similar to $89 \%$ of European couples. Only European and Afro-Caribbean mothers drank or smoked during their pregnancies. It was interesting that Indian mothers resembled European mothers regarding family size, mean parental ages and whether they worked during their pregnancies. Although antenatal care is less for mothers who have recently come to the UK than for others, the difference is small and is the same for consanguineous as it is for non-consanguineous mothers (table VII). Most mothers met a member of antenatal clinic staff who could speak their own language, and those who did not were women who could only speak Bengali, Arabic, Vietnamese, Chinese or Pashto. Asian link workers had been introduced into the antenatal clinics of Birmingham Hospitals in November 1984, with the aims of educating Asian women about the National Health Service and about the importance of antenatal care, and of providing an interpreting service. The two observations on good attendance at antenatal clinics, and on the availability of interpreters, must reflect the success of this Asian mother and baby campaign. ${ }^{16}$

The data on mean parental ages will be useful in assessing the cause of certain genetic disorders of uncertain or heterogeneous aetiology, but in which an increase in paternal age would suggest new dominant mutations. ${ }^{12}$ The mean parental ages for babies born in the United Kingdom have been provided by the Registrar General since 1962 , but not divided by race. Although there have been fluctuations in age specific fertility rates in England and Wales in the last 25 years, the current mean maternal age is now very similar to what it was 25 years ago, namely 27.4 years. ${ }^{17}$ This mean is higher than that found in mothers in the USA ${ }^{12}$ and higher than the mean of 26.0 years found for European mothers in this study.

Reliable data on the level of parental consanguinity are useful in assessing whether or not a particular familial condition is inherited as an autosomal recessive, and if so, whether it is homogeneous. ${ }^{101113}$ The most recent observations on parental consanguinity in an English population were those of Coleman who documented consanguinity in eight out of 946 $(0.84 \%)$ married couples in Reading, and who calculated a mean inbreeding coefficient of 0.00017 , which was similar to that found in current European studies. ${ }^{18}$ The mean inbreeding coefficient found here for Europeans is 0.00022 , and suggests that the fall in the level of parental consanguinity that was documented by Julia Bell between 1860 and $1940^{19}$ is not continuing, but that the level has now stabilised. Similar low levels of parental consanguinity occur in AfroCaribbeans, Sikhs and Hindus.

Parental consanguinity is usually associated with an increased risk for the occurrence of autosomal recessive disease in offspring. This increased risk is small in absolute terms if the inbreeding coefficient is 0.0625 or less and cannot be shown with the small numbers of consanguineous Europeans in this present prospective study. However a harmful effect of parental consanguinity in European babies has been clearly shown in Norway ${ }^{20}$ in a study spanning 15 years. There were significant increases in the stillbirth and neonatal mortality rates, in the malformation rate, and in all deaths occurring in the first year. Similar deleterious effects have been reported from Spain. ${ }^{21}$

There have been previous reports of high levels of consanguineous marriages in Pakistanis and Muslims, both in England ${ }^{19}$ and in Pakistan. ${ }^{22}$ The present study has confirmed this and has shown that there are no social or demographic features which clearly distinguish the women who 
marry relations from those who do not (table VII). It is important to note that the presence of several consanguineous marriages in many Muslim pedigrees brings the inbreeding coefficient above that due to a single first cousin marriage. It is also interesting that the level of consanguineous marriages of $69 \%$ of Pakistani Muslims is greater than that for Muslims from other countries, including Bangladesh (table V). Perhaps one reason lies in the fact that many of the latter marriages took place outside the United Kingdom. It has been suggested that consanguinity is practiced more often in Pakistanis settled in Britain than in those in Pakistan; ${ }^{9}$ a non-significant trend for closer consanguineous marriages to occur between younger Pakistanis than between older couples was observed here.

The Pakistanis in Birmingham originate mainly in the Mirpur area of Kashmir, in North Pakistan. The Muslim religion was introduced here in the sixteenth century, and along with its adoption came the custom of marrying relatives in order to preserve property. Because of this aim, inheritance commonly follows the male line in consanguineous Muslim pedigrees, which is in contrast to that in European inbred families, where the most frequent first cousin relationship is when the two grandmothers are sisters. ${ }^{23}$ The relatively recent introduction into the north of the Indian subcontinent of a religion which permitted marriages between blood relations has thus led to inbreeding for 10 to 15 generations, and the consequent risk of autosomal recessive disease occurring in offspring. In contrast, close consanguinity has been practised in South India for about 100 generations, and some elimination of recessive lethals may have occurred, since few harmful effects concerning malformations and fetal growth can now be shown. ${ }^{24}$ We searched in this study for an effect of parental consanguinity on birth weight, but found none, in spite of an earlier report to the contrary. ${ }^{25}$ Perhaps the lack of such an effect is due to the continuing increase in birth weights of babies of immigrants to the United Kingdom as a result of improved environment. ${ }^{26}$

Studies from Pakistan 2227 have shown that both perinatal mortality and childhood deaths are increased in the offspring of consanguineous unions, and an increased perinatal mortality for Pakistani babies has also been shown in the United Kingdom. ${ }^{1-6}$ The present documentation will serve as a basis for a five year prospective study of the health of infants and children. It will be important to assess the causes and extent of any increased mortality and morbidity, to assess whether premarital health education would be beneficial, and whether paediatricians should be alerted to high risks of particular autosomal recessive diseases, in order to initiate prompt treatment or to warn the parents of the 1 in 4 risk of recurrence.
We are grateful to the obstetricians of Birmingham Maternity, Dudley Road and Marston Green Hospitals for allowing us to interview their patients in the postnatal wards, and we thank the midwives for their help in the study. We thank Professor D F Roberts, Dr S S Bakhshi, Professor E G Knox, and Professor A S McNeish for advice in planning the study and during the study, and for their criticisms of this manuscript.

We gratefully acknowledge financial support from the Health Promotion Research Trust, and the Marie Stopes Research Fund.

1 Terry PB, Condie RG, Settatree RS. Analysis of ethnic differences in Perinatal statistics. Br Med $\mathcal{f} 1980 ; 281$ : 1307-8.

2 Macfarlane A, Mugford M. Birth Counts: statistics of pregnancy and childbirth. London: Her Majesty's Stationery Office, 1984.

3 Gillies DRN, Lealman GT, Lumb KM, Congdon P. Analysis of ethnic influence on stillbirths and infant mortality in Bradford 1975-1981. F Epidemiol Community Mortality in Bradford 1984; 38: 214-7.

4 Chitty LS, Winter RM. Perinatal mortality in different ethnic groups. Arch Dis Child 1989; 64: 1036-41.

5 Young ID, Clarke M. Lethal malformations and perinatal Young ID, Clarke $M$. Lethal malformations and perinatal
mortality: a 10 year review with comparison of ethnic mortality: a 10 year review with compar
differences. $\mathrm{Br}$ Med $\mathcal{f}$ 1987; 295: 89-91.

6 Barnes $R$. Perinatal mortality and morbidity rates in Bradford. In: McFadyen IR, MacVicar J, eds. Obstetric problems of the Asian community in Britain. London: Royal College of Obstetricians and Gynaecologists, 1982: 81-7.

7 Bundey S. The Birmingham Birth Study. Biology and Society 1988; 5: 13-15.

8 Nicoll A. Difficulties in comparing handicaps in different ethnic groups. Biology and Society 1988; 5: 81-20.

9 Darr A, Modell B. The frequency of consanguineous marriage among British Pakistanis. F Med Genet 1988; 25: 186-90.

10 Dahlberg G. Inzucht bei Polyhybriditat beim Menschen. Hereditas 1930; 14: 83-96.

11 Roberts JAF. Human pathological conditions determined Ry any one of several genes. Nature 1932; 130: 542-3.

12 Jones KL, Smith DW, Harvey MAS, Hall BD, Quan L. Older paternal age and fresh gene mutation: data on additional disorders. $\mathcal{F}$ Pediatr 1975; 86: 84-8.

13 Emery AEH. Methodology in medical genetics. 2nd ed. Edinburgh: Churchill Livingstone, 1986.

14 Thomson AM, Billewicz WZ, Hytten FE. The assessment of fetal growth. F Obstet Gynaecol 1968; 75: 903-16.

15 Gairdner D, Pearson J. Revised Gairdner-Pearson growth charts. Arch Dis Child 1985; 60: 1202.

16 Bahl V. Asian mother and baby campaign. London: Department of Health and Social Security, 1987.

17 Office of Population Censuses and Surveys. Population trends 1837-1987; 150 years of the General Register Office. London: OPCS, 1987.

18 Coleman DA. A note on the frequency of consanguineous marriages in Reading, England in 1972/1973, Hum Hered 1980; 30: 278-85.

19 Bell $\mathrm{J}$. A determination of the consanguinity rate in the general hospital population of England and Wales. Anv. Eugenics 1940; 10: 370-91

20 Maynus P, Berg K, Bjerkedal T. Association of parental consanguinity with decreased birthweight and increased rate of early death and congenital malformations. Clin Genet 1985; 28: 335-42.

21 Edo MA, Otero HR, Caro L. The influence of consanguinity on fertility and infant mortality in Sanabria (Zamora, Spain). Biology and Society 1985; 2: 129-34.

22 Shami SA, Zahida. Study of consanguineous marriages in the population of Lahore, Punjab, Pakistan. Biologia 1982; 28: 1-15.

23 Shields J. Slater E. An investigation into the children of cousins. Acta Genet Stat Med 1956; 6: 60-79.

24 Rao PSS, Inbaraj SA. Inbreeding effects on fetal growth and

25 Honeyman MM, Bahl L, Marshall T, Wharton BA. Consanguinity and fetal growth in Pakistani Moslems. Arch Dis Child 1987; 62: 231-5.

26 Clarson CL, Barker MJ, Marshall T, Wharton BA. Secular changes in birthweight of Asian babies born in Birmingham. Arch Dis Child 1982; 57: 867-71.

27 Shami SA, Schmitt LH, Bittles AH. Consanguinity related prenatal and postnatal mortality of the populations of seven 